\title{
Identification of risk factors for acute kidney injury after pulmonary endarterectomy with cardiopulmonary bypass
}

\author{
Peng Dong, Fu-Shan Xue* (D) and Shao-Hua Liu
}

\begin{abstract}
The letter to the editor made several comments on possible issues in the recent article by Zhang et al. determining the risk factors of acute kidney injury after pulmonary endarterectomy with cardiopulmonary bypass, which has been published in Journal of Cardiothoracic Surgery at December 30, 2019.
\end{abstract}

Keywords: Acute kidney injury, Cardiopulmonary bypass, Risk factors, Postoperative outcomes

\section{To the Editor:}

We read with great interest the recent article by Zhang et al. [1] determining the risk factors of acute kidney injury (AKI) after pulmonary endarterectomy with cardiopulmonary bypass $(\mathrm{CPB})$. By univariate and multivariate logistic regression analyses, they showed that preoperative platelet count and hemoglobin level, and deep hypothermic circulatory arrest time were the independent predictors of postoperative AKI. Other than the limitations described by the authors in discussion, however, we noted several issues in this study that were needed further clarifications.

First, $12(9.8 \%)$ patients were defined as preoperative renal dysfunction only based on the serum creatinine (SCr) level of greater than $1.2 \mathrm{mg} / \mathrm{dL}$. It must be emphasized that alone use of this variable to assess baseline renal function has a limited value, as many factors can significantly affect preoperative $\mathrm{SCr}$ levels. The available evidence indicates that preoperative occult renal dysfunction, a most established risk factor for postoperative $\mathrm{AKI}$, is common among patients with a normal $\mathrm{SCr}$

\footnotetext{
* Correspondence: xuefushan@aliyun.com; fushanxue@outlook.com Department of Anesthesiology, Beijing Friendship Hospital, Capital Medical University, No. 95 Yong-An Road, Xi-Cheng District, Beijing 100050, People's Republic of China
}

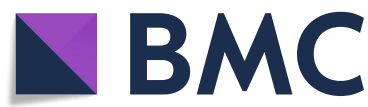

level, with a prevalence of $49.1 \%$ [2]. In clinical practice, the useful and reliable methods to determine preoperative occult renal dysfunction actually are combined use of SCr levels and $\mathrm{SCr}$ clearance, and use of estimated glomerular filtration rate criteria of the National Kidney Foundation Kidney Disease Outcomes Quality Initiative Classification. We were concerned that alone use of the $\mathrm{SCr}$ levels to assess preoperative renal function would have underestimated the incidence of occult renal dysfunction in this study, resulting in the possibility that an important risk factor for postoperative AKI was not demonstrated to be significant in this study.

Second, the readers were not provided with intraoperative and postoperative fluid volumes and fluid balance, though perioperative fluid overload is frequent among patients with $\mathrm{CPB}$ surgery and has been independently associated with an increased risk of postoperative AKI [3]. Most important, moreover, it was unclear whether the $\mathrm{SCr}$ levels used for difination of postoperative AKI had been adjusted based on periostoperative fluid balance. As a positive fluid balance may dilute SCr levels, not adjusting $\mathrm{SCr}$ levels for periostoperative fluid balance can underestimate incidence and severity of AKI after $\mathrm{CPB}$ surgery. The recent evidence indicates that a

(C) The Author(s). 2020 Open Access This article is licensed under a Creative Commons Attribution 4.0 International License, which permits use, sharing, adaptation, distribution and reproduction in any medium or format, as long as you give appropriate credit to the original author(s) and the source, provide a link to the Creative Commons licence, and indicate if changes were made. The images or other third party material in this article are included in the article's Creative Commons licence, unless indicated otherwise in a credit line to the material. If material is not included in the article's Creative Commons licence and your intended use is not permitted by statutory regulation or exceeds the permitted use, you will need to obtain permission directly from the copyright holder. To view a copy of this licence, visit http://creativecommons.org/licenses/by/4.0/ The Creative Commons Public Domain Dedication waiver (http://creativecommons.org/publicdomain/zero/1.0/) applies to the data made available in this article, unless otherwise stated in a credit line to the data. 
small increase of early postoperative $\mathrm{SCr}$ levels adjusted for fluid balance after CPB surgery can significantly improve diagnosis and severity classifications of AKI defined by the Kidney Disease: Improving Global Outcomes criteria used in this study [4].

Third, the authors did not provide the details of intraoperative hemodynamic instability, hemoglobin levels, perfusion pressure and rate during $\mathrm{CPB}$, and intraoperative use of vasopressin. In fact, both hypoperfusion and low mean arterial pressure during $\mathrm{CPB}$ are the most established risk factors for postoperative AKI in patients undergoing cardiac surgery [5]. Furthermore, both hemodilution anemia and hypotension during $\mathrm{CPB}$ can synergistically act to increase the risk of postoperative AKI [6]. In addition, an increased dose of vasopressin during surgery has been associated strongly with an increased risk of AKI after cardiac surgery [3].

Fourth, a 7-day observed period was used for determination of AKI and early postoperative adverse events were well noted in this study. Other than postoperative nadir hemoglobin level, however, most of early postoperative adverse events associated with the occurrence of postoperative AKI seemed not to be taken into the univariate and multivariate models for statistical adjustment. It is generally believed that low cardiac output syndrome, hemorrhage requiring reexploration, sepsis, infection, pulmonary complications, hypotension and blood transfusion in early postoperative period are significantly associated with an increased risk of AKI after CPB surgery [7].

Finally, directly comparing postoperative short-term outcomes including the lengths of hospital and intensive care unit stay, duration of mechanical ventilation and 90-day mortality between patients with and without postoperative AKI or among patients with different postoperative AKI stage, was questionable, as their preoperative and intraoperative data that might affect postoperative short-term outcomes were significantly different. To obtain the true effects of AKI occurrence and severity on postoperative short-term outcomes in a retrospective study, the multivariate analysis or propensity score matching for adjustment of confounders is needed.

Thus, we argue that clarification of above issues will improve the transparency of this study design and be very helpful for interpretation of the findings.

Abbreviations

SCr: Serum creatinine; AKI: Acute kidney injury; CPB: Cardiopulmonary bypass

\section{Acknowledgements}

None of the authors receive financial support and has potential conflicts of interest for this work.

\section{Authors' contributions}

All authors had carefully read the manuscript of Zhang et al, analyzed their methods and data. PD and FSX suggested comment points and drafted this manuscript. SHL revised comment points and this manuscript. All authors read and approved the final manuscript.
Funding

There is no financial support for this work.

Availability of data and materials

Not applicable.

Ethics approval and consent to participate

As our paper is just a letter to the editor that comments a article published in journal, both ethics approval and consent are unnecessary.

\section{Consent for publication}

All authors agree to the contents of the submitted manuscript and acknowledge familiarity with the journal's instructions for manuscript submission.

\section{Competing interests}

The authors declare that they have no competing interests.

Received: 27 February 2020 Accepted: 10 May 2020

Published online: 15 May 2020

References

1. Zhang C, Wang G, Zhou H, et al. Preoperative platelet count, preoperative hemoglobin concentration and deep hypothermic circulatory arrest duration are risk factors for acute kidney injury after pulmonary endarterectomy: a retrospective cohort study. J Cardiothorac Surg. 2019; 14(1):220.

2. $\mathrm{XuJ}, \mathrm{Yu} J, \mathrm{Xu} X$, et al. Preoperative hidden renal dysfunction add an age dependent risk of progressive chronic kidney disease after cardiac surgery. J Cardiothorac Surg. 2019;14(1):151.

3. Haase-Fielitz A, Haase M, Bellomo R, et al. Perioperative hemodynamic instability and fluid overload are associated with increasing acute kidney injury severity and worse outcome after cardiac surgery. Blood Purif. 2017; 43(4):298-308.

4. Jin J, Chang SC, Xu S, et al. Early postoperative serum Creatinine adjusted for fluid balance precisely predicts subsequent acute kidney injury after cardiac surgery. J Cardiothorac Vasc Anesth. 2019;33(10):2695-702.

5. Coleman MD, Shaefi S, Sladen RN. Preventing acute kidney injury after cardiac surgery. Curr Opin Anaesthesiol. 2011;24(1):70-6.

6. Haase M, Bellomo R, Story D. Effect of mean arterial pressure, haemoglobin and blood transfusion during cardiopulmonary bypass on post-operative acute kidney injury. Nephrol Dial Transplant. 2012;27(1):153-60.

7. Wang Y, Bellomo R. Cardiac surgery-associated acute kidney injury: risk factors, pathophysiology and treatment. Nat Rev Nephrol. 2017;13(11):697-711.

\section{Publisher's Note}

Springer Nature remains neutral with regard to jurisdictional claims in published maps and institutional affiliations.

Ready to submit your research? Choose BMC and benefit from:

- fast, convenient online submission

- thorough peer review by experienced researchers in your field

- rapid publication on acceptance

- support for research data, including large and complex data types

- gold Open Access which fosters wider collaboration and increased citations

- maximum visibility for your research: over $100 \mathrm{M}$ website views per year

At BMC, research is always in progress.

Learn more biomedcentral.com/submissions 